\title{
Stratejik Planların Teoriden Pratiğe Proje Üretim Sürecinin Analizi: Büyükşehir Ulaşım Ana Planları Örneklemi
}

\author{
Hayri Ulvi \\ Gazi Üniversitesi \\ ORCID: 0000-0003-2988-6215
}

Öz

Ulaşım ana planları, kentsel alanlarda ulaşım sorunları çözmek amacıyla gerçekleştirilen yasal planlama araçlarından birisidir. Günümüzde farklı nitelikteki kentlerin kentsel ulaşım konusunda çektiği sıkıntılar farklılaşsa da yaşanan sorunlara çözüm üretmenin yolu ulaşım ana planının yapılmasına bağlıdır. Ulaşım ana planı yapmayı gündemine alan kurum, kuruluş veya kişilerin ulaşım ana planı çalışmalarım başarılı bir şekilde tamamlamasını sağlaması adına hazırlanmış, kılavuz niteliğinde kullanılması için hazırlanan dokümanlardan biriside Türkiye belediyeler birliği ulaşım çalışma komisyonunun katkılarıyla hazırlanan ulaşım planlama çalışmaları ve ulaşım ana planı hazırlama kılavuzu olarak literatürde yer almaktadır. Bu çalışma kapsamında yapılan değerlendirme Türkiye'de geçmişten günümüze devam eden süreç içerisinde yapılmış ulaşım ana planı çalışmalarına odaklanmaktadır. Türkiye belediyeler birliğinin katkılarıla hazırlanan kılavuz temel alınarak çalışma kapsamındaki ulaşım ana planlarının kılavuz kapsamında hangi derecede gerçekleştiğine yönelik tespitler yapılmaktadır. Çalışma sonucunda Türkiye'de ulaşım ana planlarının birbirinden farklı olan yönleri ve bahsedilen farklılı̆̆a ilişkin değerlerin yanı sıra ulaşım ana planı çalışmalarının daha verimli nasıl yapılabileceğine dair öneriler detaylı yönleri ile ifade edilmektedir.

Anahtar Kelimeler: Ulaşım ana planı, kent içi ulaşım, büyükşehir belediyeleri.

idealkent (c) Kent Araştırmaları Dergisi (Journal of Urban Studies)

http://idealkentdergisi.com

Geliş Tarihi Received Date: 15.05.2019 Kabul Tarihi Accepted Date: 31.08.2019 


\title{
Analysis of the Project Production Process from Theory to Practice of Strategic Plans: Sample of Great Municipality Transportation Master Plans *
}

\author{
Hayri Ulvi \\ Gazi University \\ ORCID: 0000-0003-2988-6215
}

\begin{abstract}
Transportation master plans are one of the legal planning tools to solve transportation problems in urban areas. Although the problems of different cities in urban transportation are different, the way to produce solutions to the problems is dependent on making the transportation master plan. For organizations, or persons transportation which intended master plan studies prepared on behalf of ensuring the successful completion of documents produced for use in manual nature of someone in Turkey association of municipalities transportation study prepared with the contribution of commission transport planning and transport in the literature as a guide to prepare the master plan is located at. In this study, the assessment made in transportation ongoing process in Turkey from past to present work focuses on the master plan. Turkey prepared with the contribution of municipalities that guide the transportation master plan under the scope of manual work is carried out based on the determinations about what degree of place. aspects that are different from each other and the transportation master plan in Turkey, said the study results as well as differences of values for more efficient transport master plan study recommendations on how it can be done is expressed with detailed directions.
\end{abstract}

Keywords: Transportation master plan, urban transportation, greater municipalities. 


\section{Giriş}

Kentler, görece olarak yerleşim alanlarının daha fazla yapı içeren alanları$\mathrm{n}$ ifade eden kavramlar olarak bilinmektedir. İnsanların yaşam alışkanlıklarının bir sonucu olarak ekonomik, sosyal ve çevresel boyutlara sahip ihtiyaçları doğmaktadır. Bu tür ihtiyaçların kent üzerinde belli noktalar üzerinde yer alması kente özgü bir arazi kullanım deseninin oluşmasına katkı vermektedir. İnsanların kent ile etkileşimi iki temel bileşen üzerinden gerçekleşmektedir. Birincisi ekonomik, sosyal ve çevresel muhteviyatlı gereksinimler için ilgili mekânlarda yer almak şeklindedir. İkincisi ise ilgili mekânlarda yer almak için oraya ulaşımın sağlanması şeklindedir (Akbulut, 2016, s.338).

Kent içi ulaşım insanların yaşamsal aktivitelerine erişimde ana rolü üstlenmektedir. Ulaşım için iki boyutta bileşen tanımlanabilir. Bileşenlerden birisi fiziksel anlamda insan ve yüklerin bir noktadan diğer noktaya varmasında kullanılan izleri, aksları ifade ederken diğeri ise izler ve aksların üzerinde hangi tür imkânlar ile ulaşımın gerçekleştirileceğine yönelik değerlendirilebilir (Hamamcıŏlu, 2009, s.13).

Buradan çıkarımla kent içi ulaşımda yollar, iz ve aksları temsil etmekte ulaşım imkânları olarak bahsedilen kavram ise yapılan yolculuğun hangi şekilde gerçekleştiğini ifade etmektedir. Kent içi ulaşımda insanlar yolculuğa başladığı bir noktada diğer noktaya giderken yolları kullanırken günümüzde teknolojinin elverişliliğine bağlı olarak farklı ulaşım imkânlarindan yararlanabilmektedir (Akman ve Alkan,2016,s.55).

Kentteki diğer mekânlarda olduğu gibi ulaşım ihtiyacı iki mekân arasındaki bağlantıyı gerektirdiğinden mekânlar arasında bağlantılar oluşturulmaktadır. Kentsel mekânlar arasında bağlantı oluşturmanın en temel şekillerinden birisi de izler ve akslardan yararlanmaktır. Ulaşım konusunda kent içi yerleşimin arazi kullanım desenine göre mekânlar arasındaki bağlantıların özellikleri hiyerarşik değişiklikler göstermektedir. Bundan dolayı arazi kullanım desenine bağlı olarak farklılaşan ulaşım talep düzeyi kentten kente, yerleşimden yerleşime farklı çözümlerin üretilmesine gerek duyabilmektedir.

Kent içi ulaşım günümüzde kent otoritelerinin sıklıkla gündeminde yer alan bir konu olarak karşımıza çıkmaktadır. Bunun en temel sebeplerinden birisi kent içi ulaşım kavramının ekonomik, sosyal ve çevresel yönlerinin bulunmasıdır. Kent içi ulaşım kavramında yaşanan sıkıntıların eko- 
nomik, sosyal ve çevresel yansımalarının olması üretilen çözümlerinde hassas olmasını gerektirmektedir (Önder ve Akdemir, 2019, s.26).

Kent içi ulaşım da yaşanan sorunlara kapsamlı çözümler üretmenin yolundan birisi de ulaşım ana planı çalışmalarıdır. Ulaşım ana planı çalışmaları ağırlıklı olarak kent içi ulaşım göz önünde bulundurularak kentin ulaşım ile ilgili sorunlarının çözüme kavuşturulduğu, yazılı ve çizili belgelerden oluşan mevcut ve yeni bilgilerden faydalanarak, tahmin çalışmaları ile desteklenen, sayısal bir model kurularak yetersizlik, sorun ve darboğazların etkisinin azaltılmaya ve ortadan kaldırılmaya çalışıldığı bir planlama uğraşıdır (Hamurcu ve Eren,2018, s.202).

Ulaşım ana planları çözüme ulaştırmayı hedeflediği sorunlar açısından kentlerde benzer bir iş sürecini gerektirse de her kentin farklı nitelikteki dinamik yapısı iş süreci açısından farklılıklar gözlemlenebilmektedir (Ayataç, 2016, s.31).

\section{Yöntem}

Kentlerde yaşanan ulaşım problemleri ulaşım altyapısının kapasite özelliklerine dayalı olarak ortaya çıkmaktadır. Sosyo - ekonomik anlamda yaşanan değişimler ulaşım altyapı kapasitesinin farklı talep seviyelerinde kullanılmasını sağlayabilmektedir. Bu durumdan dolayı farklı zaman dilimlerinde aynı kentsel mekânın ulaşım altyapısında yetersizlikler dolayısıyla sorunlar yaşanabilmektedir. Ulaşım alanında kentsel mekânın konusu olan sorunları çözmenin yollarından biriside ulaşım ana planlarıdır. Ulaşım ana planları aracılığıyla kent ulaşımına ilişkin makro - mikro ölçekli sorunlara ilişkin çözüm önerileri geliştirilebilmektedir. Ulaşım ana planı proje üretimi süreci kentin geleceğine ilişkin durumlara ilişkin sonuç ürünler ortaya koyduğundan sürecin hassas bir şekilde yürütülmesini gerektirmektedir (Oral, 2011, s. 73).

Ulaşım ana planı, kenti ilgilendiren diğer birçok planda olduğu gibi genel olarak geleceğe yönelik bir tahmin etme işidir. Kendine ilişkin yöntemleri olan matematiksel modellerden yararlanarak kentlerin ulaşım hedefleri doğrultusunda şekillenen ulaşım ana planlarında amaç yaşanan sorun ve yetersizlikleri çözüme kavuşturmaktır (Özalp ve Öcalır, 2008, s. 75).

Planlama disiplini açısından değerlendirildiğinde $1 / 25.000$ ve $1 / 5.000$ ölçekli planlama çalışmaları arasında yer alan ulaşım ana planları birbirinden farklı iş kalemlerinin meydana getirdiği bir planlama uğraşıdır. 
Ulaşım konusunda planlama uğraşının gerçekleşebilmesi için Türkiye'de, Türkiye belediyeler birliği ulaşım çalışma komisyonunun katkılarıyla hazırlanan ulaşım planlama çalışmaları ve ulaşım ana planı hazırlama kılavuzu kapsamlı bir dokümandır (TBB, 2014).

$\mathrm{Bu}$ dokümanın yapısı genel hatlarıyla ulaşım planlama çalışmalarının kapsamını, tanımları, trafik konusundaki etüt ve projeleri, uygulanması potansiyel projelerin değerlendirilmesine ilişkin fizibilite çalışmalarını ifade etmektedir. Dokümanın ulaşım planlama çalışmaları açısından detaylı bir şekilde değerlendirilmesi yapıldığında kapsamlı bir şekilde ulaşım ana planlarının başlangıcından tamamlanmasına kadar bütün iş akış sürecini ve iş akış sürecindeki gerekliliklere yer verildiği görülmektedir.

Ulaşım ana planları kapsamında Türkiye'de projelerin yapılmasına kaynak oluşturan yani finansman sağlayan kurumlardan birisi de yerel idarelerden birisi olan belediyelerdir. Belediyeler hizmet üretmek zorunda olduğu yerleşmelerin ulaşım problemlerinin çözümünde ulaşım ana planlarını bir çözüm aracı olarak kullanmaktadır. Ulaşım ana planlarının çözüm üretmek için bir araç kullanılmasında etkinliğinin artması için Türkiye belediyeler birliğinin hazırlamış olduğu doküman ulaşım ana planlarının yapılmasında gerekli olan çalışmalardaki detayları açıklaması yönüyle bir rehber niteliği görmektedir.

Ulaşım ana planı hazırlama rehberi niteliği taşıyan söz konusu dokümanın ulaşım ana planı çalışmalarının kolayca algılanabilmesi için ulaşım ana planını 7 ana iş kalemine ayırdığı yorumu yapılabilir. Bu çerçevede bakıldığında 7 iş kalemi tabloda ifade edildiği gibidir.

Tablo 1. Ulaşım Ana Planları İş Kalemleri (TBB,2014)

\begin{tabular}{cc}
\hline & \multicolumn{1}{c}{ İş Kalemleri } \\
\cline { 2 - 2 } Ulaşım & Mevcut Bilgilerin Toplanması ve Değerlendirilmesi \\
\cline { 2 - 2 } Ana Planı & Yeni Bilgilerin Toplanması ve Değerlendirilmesi \\
\cline { 2 - 2 } & Ulaşım Talep Tahmin Modelinin Kurulması ve Kalibrasyonu \\
\cline { 2 - 2 } & Hedef Yılı Projeksiyonu \\
\cline { 2 - 2 } & Setersizlik ve Sorun Analizi \\
\hline
\end{tabular}


Tablodan görüldügü üzere ulaşım ana planının üretim süreci mevcut bilgilerin toplanması ile başlamaktadır. Mevcut bilgilerin toplanması iş kalemini ihtiyaç duyulan yeni bilgilerin edinimi, ulaşım talep tahmin modelinin kurulması ve kalibrasyonu takip etmektedir. Planlama faaliyeti geleceğe yönelik kestirimlere ilişkin kararları içerdiğinden dolayı çözüm üretilmek istenen menzile bir diğer ifade ile hedef yılına ilişkin tahminlerin yapılması gerektirmekte olup bu da ulaşım ana planının önemli bir parçası olarak karşımıza çıkmaktadır. Ulaşım ana planları temel olarak ilgili yerleşim alanındaki ulaşım sorunlarını çözmeye yönelik olarak gelişmektedir. Bu durum ulaşım ana planları çerçevesinde detaylı bir yetersizlik ve sorun analizinin yapılmasına gereksinim oluşturmaktadır.

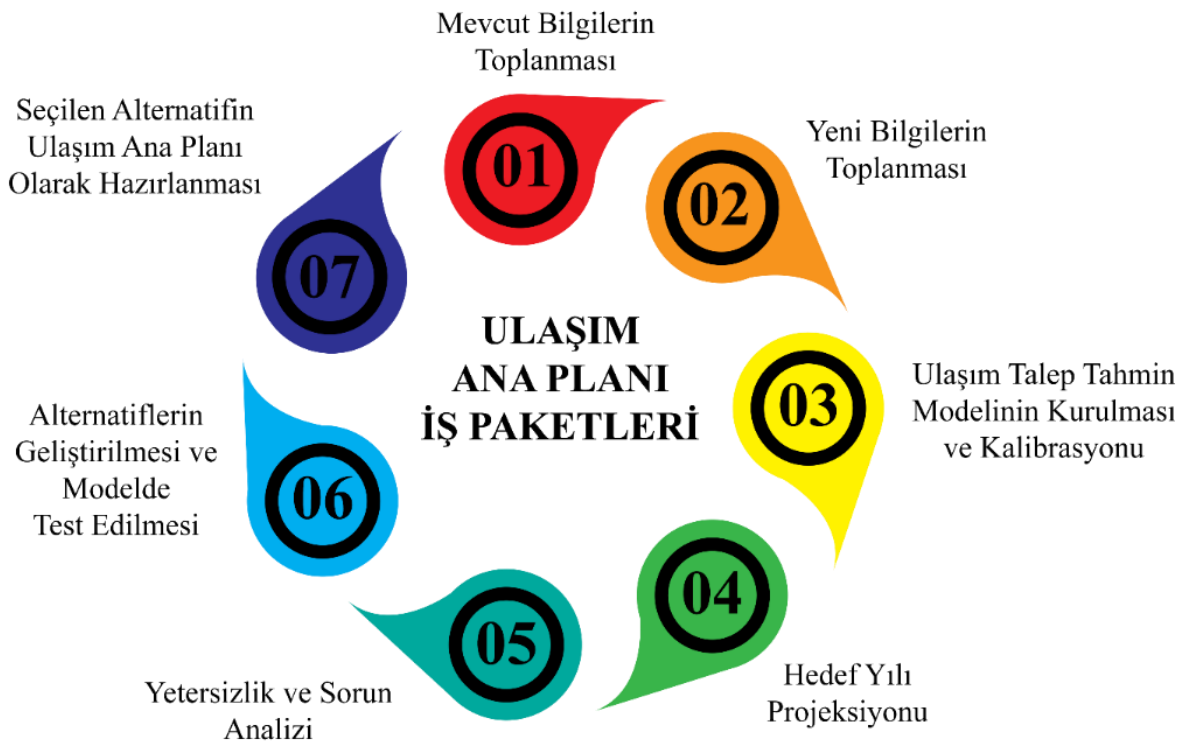

Şekil 1. Ulaşım Ana Planı İş Paketleri

Ulaşım ana planları mevcutta ve gelecek için tespit edilen sorun ve yetersizliklerin önüne geçmek amaciyla üretilmektedir. Bunun için daha önceden yapılan hesaplamalar doğrultusunda çözüm alternatifleri geliştirilmekte çözüm potansiyelleri konusunda incelemelerin yapıldığ1 görülmektedir. $\mathrm{Bu}$ aşama ulaşım ana planlarında alternatiflerin geliştirilmesi ve modelde test edilmesi şeklinde gerçekleşmektedir.

Yapılan çalışmaların ulaşım ana planı olarak projelendirilmesi üretilen fikirler kapsamında sadece bir alternatifin seçilmesini gerektirmekte- 
dir. Ulaşım ana planı kapsamında üretilen fikirler çeşitli yöntemler aracılığıyla ele alınıp bir karar mekanizması oluşturulmaktadır. Karar mekanizmasının sonuç bir ürünü olarak ortaya çıkan alternatif kent için yaşanan ulaşım problemlerini çözmekte ulaşım ana planı kanalı ile oluşturulan sonuç üründür.

Ulaşım ana planı ifade edildiği üzere birbirinden farklı nitelikte ancak birbirini etkileyen işler ile meydana getirilmektedir. Her iş kalemine ilişkin sürecin özenli ve düzgün bir şekilde tamamlanması ilgili iş sürecinin kendinden sonraki adımının düzgünce tamamlanmasında dolayısı ile ulaşım ana planının ortalama başarısında etkin bir rol oynamaktadır. Örnek olarak mevcut durum hakkında yeteri bir veri toplanmasının gerçekleşmediği bir ulaşım ana planında yetersizlik ve sorunlar iş kaleminin ulaşım ana planına konu olan yerleşim ile ilgili tüm sorunlara doğru bir şekilde ışık tutması beklenemez ya da kestirim konusu ile ilgili çalışmaların eksik olduğu bir ulaşım ana planı çalışmasında üretilen çözüm alternatiflerinin yeterince işe yarar şekilde çalışması söz konusu olamaz. Bundan dolayı ulaşım ana planlarının iş akış sürecinde yer alan iş kalemlerinin her birinde hassasiyetle çalışmak gerektiği sonucu ortaya çıkmaktadır.

Birbirinden farklı 7 ana iş kaleminden oluşan ulaşım ana planı çalışmalarında mevcut duruma ilişkin verilerin toplanmasından kent için ulaşım anlamında elde edilmek istenen alternatif çözümün gerekçelendirilmesine kadar ilerleyen bir süreç takip edilmektedir.

Her kentin farklı bir dinamiğe sahip olmasından dolayı ulaşım anlamında yaşanan sorunlar ve dolayısıyla üretilecek çözümlerin de farklı olması söz konusu olabilmektedir. Temel olarak ulaşım ana planlarının çözüm ürettikleri odaklar;

1- Toplu taşıma sistemleri,

2- Özel taşıt

şeklinde olmaktadır.

Yaya ulaşımı, bisiklet ulaşımı, karayolu ulaşımı altyapısı, engelsiz ulaşım, ara toplu taşıma, taksi, servis gibi konular planın gerçekleştiği alanın ihtiyacına detaylanarak şekillenmektedir.

Ulaşım ana planı kapsamında üretilmesi gereken iş kalemlerinin birbirinden farklı alt iş kalemlerinden oluşması söz konusudur. Bu durum tabloda şu şekilde yer almaktadır. 
Tablo 2. Ulaşım Ana Planları Ana ve Alt İş Kalemleri (TBB,2014)

Ulaşım Ana Planı Ana İş $\quad$ Alt İş Kalemleri

Kalemleri

\begin{tabular}{|c|c|}
\hline \multirow{9}{*}{$\begin{array}{l}\text { Mevcut Bilgilerin Toplanma- } \\
\text { s1 ve Değerlendirilmesi }\end{array}$} & Kent Genel Yapısı \\
\hline & Karayolu Ulaşımı \\
\hline & Belediye Otobüs ve İşletmesi \\
\hline & Çevre Yerleşimlerin Toplu Taşım Servisleri \\
\hline & Şehirlerarası Terminaller \\
\hline & Kent İçi Yük Taşımaları \\
\hline & Ara Toplu Taşım İşletmeciliği \\
\hline & Bisiklet ve Alt Yapısı \\
\hline & Yaya Ulaşımı \\
\hline \multirow{9}{*}{$\begin{array}{l}\text { Yeni Bilgilerin Toplanması } \\
\text { ve Değerlendirilmesi }\end{array}$} & Hanehalkı Ulaşım Anketi \\
\hline & Yurt Anketleri \\
\hline & Karayolu Trafik Sayımları \\
\hline & Diş İstasyon Anketleri \\
\hline & Karayolu Altyapı Envanteri \\
\hline & Karayolu ve Toplu Taşım Hız Etütleri \\
\hline & Bisikletli ve Motosikletli Anketleri \\
\hline & Yaya Anketleri \\
\hline & Otopark Anketleri \\
\hline \multirow{5}{*}{$\begin{array}{l}\text { Ulaşım Talep Tahmin Modeli } \\
\text { Kurulması ve Kalibrasyonu }\end{array}$} & Verilerin Analizi ve Model Girdilerinin Hazırlanması \\
\hline & Yolculuk Üretim/Çekim Değerlerinin Hesaplanması \\
\hline & $\begin{array}{l}\text { Yolculuk Dağıtımı (Yolculuk Üretim Çekim Değerle- } \\
\text { rinin Yol Ağına Dağıtımı) }\end{array}$ \\
\hline & Türel Ayrım \\
\hline & Yolculuk Atamaları \\
\hline Hedef Yılı Projeksiyonları & Projeksiyon Yapılması \\
\hline Yetersizlik Analizi & Yetersizlik ve Sorunların Belirlenmesi \\
\hline \multirow{14}{*}{$\begin{array}{l}\text { Alternatiflerin Geliştirilmesi } \\
\text { ve Modelde Test Edilmesi }\end{array}$} & Senaryo Hazırlama \\
\hline & Senaryo Ön Değerlendirmesi \\
\hline & Senaryoların Karşılaştırılması \\
\hline & Senaryoların Çok Ölçütlü Değerlendirilmesi \\
\hline & Senaryoların Değerlendirilmesi \\
\hline & Toplu Taşıma Hizmetleri \\
\hline & Ara Toplu Taşıma Hizmetleri \\
\hline & Karayolu Şebekesi Genel Düzenleme ve Politikaları \\
\hline & Otopark Düzenlemeleri \\
\hline & Çevre Yerleşimlerle Ulaşım \\
\hline & Kent İçi Yük Taşımacılığı \\
\hline & Şehirsel Ulaşım Bağlantıları \\
\hline & Bisiklet \\
\hline & Yaya Ulaşımı \\
\hline
\end{tabular}


Bu çalışma kapsamında Türkiye Belediyeler Birliği tarafından hazırlanan ulaşım planlama çalışmaları ve ulaşım ana planı hazırlama kılavuzu göz önünde bulundurularak Türkiye'de günümüze kadar yapılan çeşitli ulaşım ana planları derlenerek karşılaştırmalı bir inceleme yapılmaktadır. İncelemeye Türkiye'nin farklı yerlerinde yaklaşık 20 adet kenti konu olmaktadır. Bu kentler tabloda verildiği gibidir.

Tablo 3. Ulaşım Ana Planı İncelenen Kentler Tablosu

\begin{tabular}{|c|c|}
\hline & Antalya (Antalya UAP, 2014) \\
\hline & Mersin (Mersin UAP, 2010) \\
\hline & Sakarya (Sakarya UAP, 2011) \\
\hline & Samsun (Samsun UAP, 2001) \\
\hline & İzmir (İzmir UAP, 2009) \\
\hline & Diyarbakır (Diyarbakır UAP, 2011) \\
\hline & Hatay (Hatay UAP, 2016) \\
\hline & Malatya (Malatya UAP, 2017) \\
\hline & İstanbul (İstanbul UAP, 2016) \\
\hline & Gaziantep (Gaziantep UAP, 2015) \\
\hline 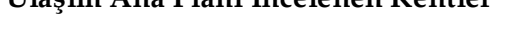 & Manisa (Manisa UAP, 2014) \\
\hline & Kocaeli (Kocaeli UAP, 2010) \\
\hline & Eskişehir (Eskişehir UAP, 2016) \\
\hline & Kayseri (Kayseri UAP, 2016) \\
\hline & Bursa (Bursa UAP, 2010) \\
\hline & Erzurum (Erzurum UAP, 2013) \\
\hline & Erzincan (Erzincan UAP, 2017) \\
\hline & Ankara (Ankara UAP, 2013) \\
\hline & Rize (Rize UAP, 2018) \\
\hline & Konya (Antalya UAP, 2001) \\
\hline
\end{tabular}




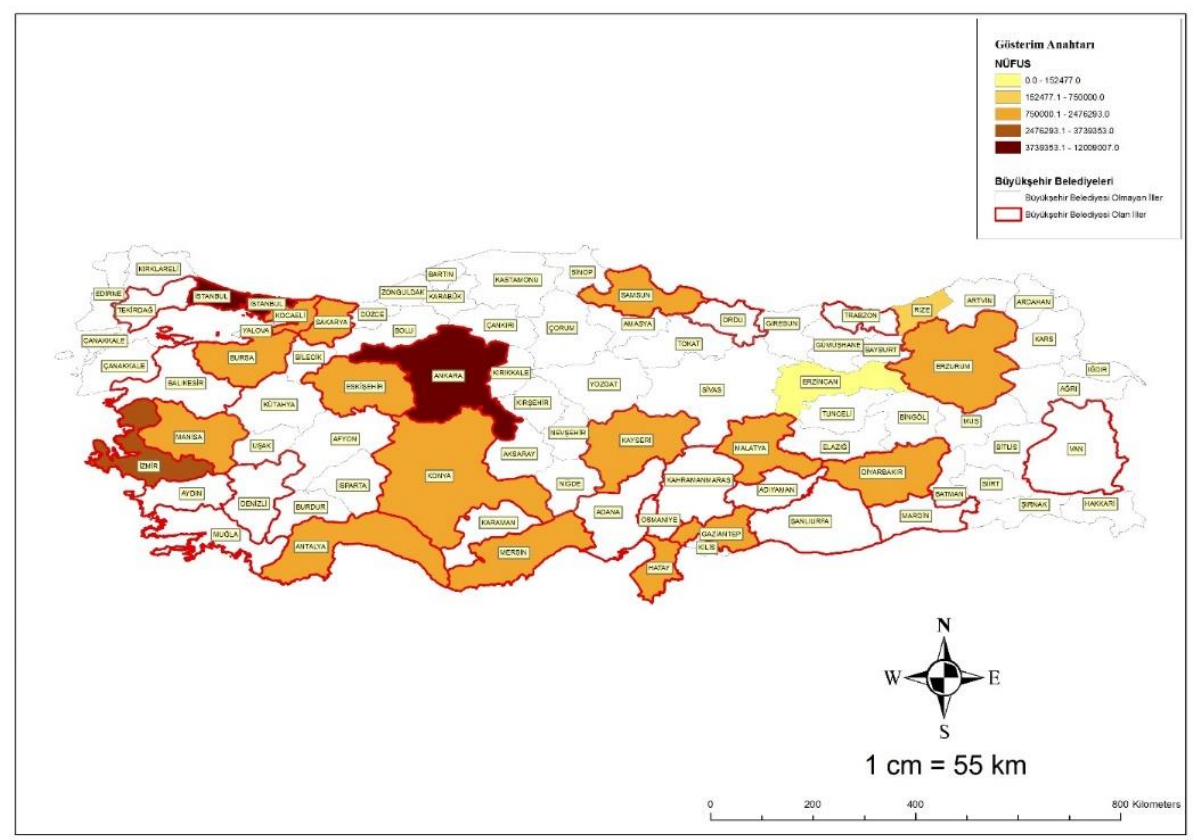

Harita 1. Mevcut Bilgilerin Toplanması ve Değerlendirilmesi

Tablo' da belirtilen kentlerde ulaşım ana planlarının karşılaştırmalı değerlendirme yapılarak incelenmesi ulaşım ana planlarının Türkiye Belediyeler Birliği tarafından hazırlanan kılavuzda yer alan iş akış sürecini oluşturan 7 ana iş kaleminin alt başlıkları ve alt başlıklarda yer alan iş tanımlarına uygun olarak ele alınmaktadır.

Çalışma kapsamının evren örneklem ilişkisi açısından büyükşehir belediyeleri ağırlıklı olarak bir yaklaşım izlemesi söz konusudur. Yaklaşık 30 Büyükşehir belediyesinin \%60'1 (16) çalışma kapsamında ele alınmaktadir.

Ele alınma sürecinde ise incelenen ulaşım ana planında kılavuzda belirtilen işin kılavuzdaki tanımına uygun olarak yerine getirilip getirilmediğine bakılmaktadır. Kılavuzda tanımlanan şekilde tamamlanan her iş için bir puan tamamlanmayan her iş için ise sıfır puan değerlendirilmesi yapılmaktadır. Sonuç olarak ise ulaşım ana planının ilgili iş paketinden aldığ 1 değer alabileceği maksimum değere oranlanarak yüzde cinsinden ne kadar başarılı olduğu ve tüm tamamlanması gereken iş kalemleri açısından ne kadar başarılı olduğu yönünde bir yorum ortaya konulmaktadır. 
İş Paketleri - ulaşım ana planı ve alınabilecek toplam puanlar tabloda olduğu şekildedir.

Tablo 4. Ulaşım Ana Planı İş Kalemleri Puan Tablosu

\begin{tabular}{lll}
\hline & Mevcut Bilgilerin Toplanması ve Değerlendirilmesi & 71 \\
\cline { 2 - 3 } Mevcut Bilgilerin & Yeni Bilgilerin Toplanması ve Değerlendirilmesi & 46 \\
\cline { 2 - 3 } Toplanması ve & Ulaşım Talep Tahmin Modelinin Kurulması ve Kalibrasyonu & 12 \\
\cline { 2 - 3 } Değerlendirilmesi & Hedef Yılı Projeksiyonu & 7 \\
\cline { 2 - 3 } & Yetersizlik ve Sorun Analizi & 7 \\
\cline { 2 - 3 } & Alternatiflerin Geliştirilmesi ve Modelde Test Edilmesi & \multicolumn{1}{c}{ Seçilen Alternatifin Ulaşım Ana Planı Olarak Hazırlanması } \\
\cline { 2 - 3 } & \multicolumn{1}{c}{ Toplam } & 241 \\
\hline
\end{tabular}

\section{Bulgular}

Çalışma kapsamında ulaşım ana planları Türkiye belediyeler birliği kapsamında ele alınarak değerlendirildiğinde her iş kalemine göre farklı sonuçların ortaya çıktığı görülmektedir. Sonuçlar iş kalemi bazında ifade edilmek istenirse karşılaştırmalar şu şekilde olmaktadır.

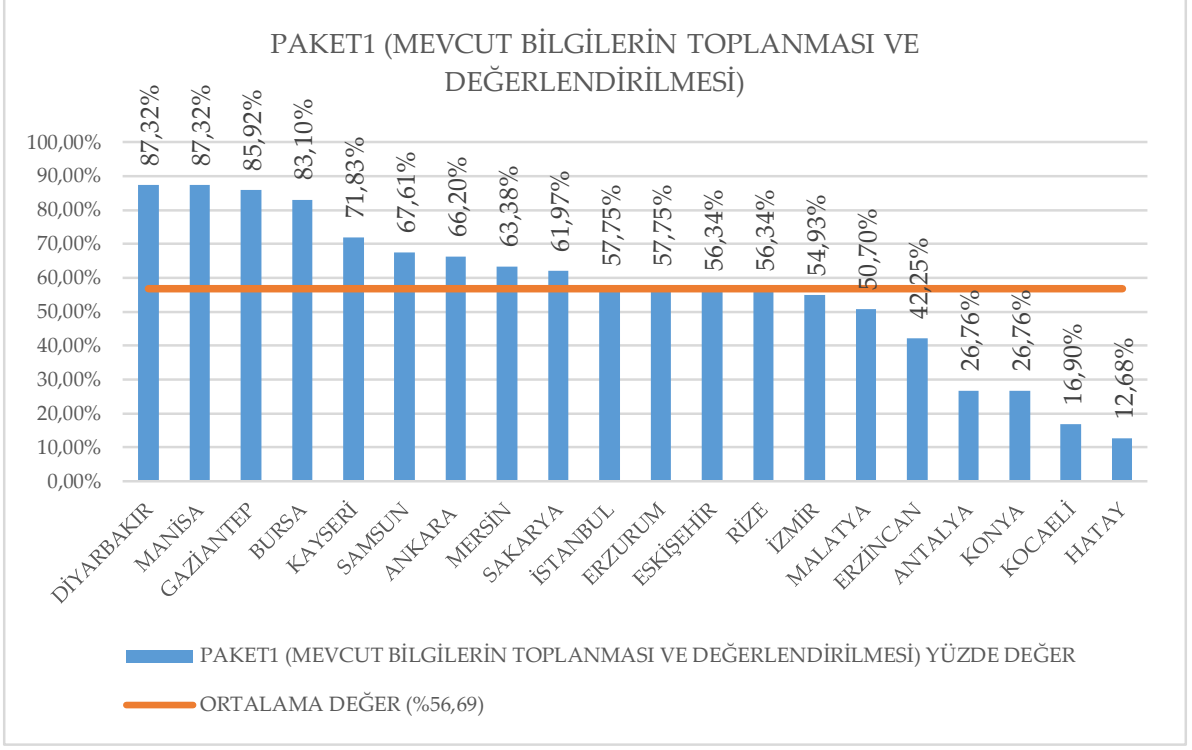

Grafik 1. İş Paketi 1 Kapsamında Yapılan Değerlendirme

Paket 1 kapsamındaki grafik incelendiğinde ortalama \%56,69'luk bir başarı sağlandığı görülmektedir. Toplamda 7 ilin ortalama başarı sınırının altında kaldığg görülmektedir. 


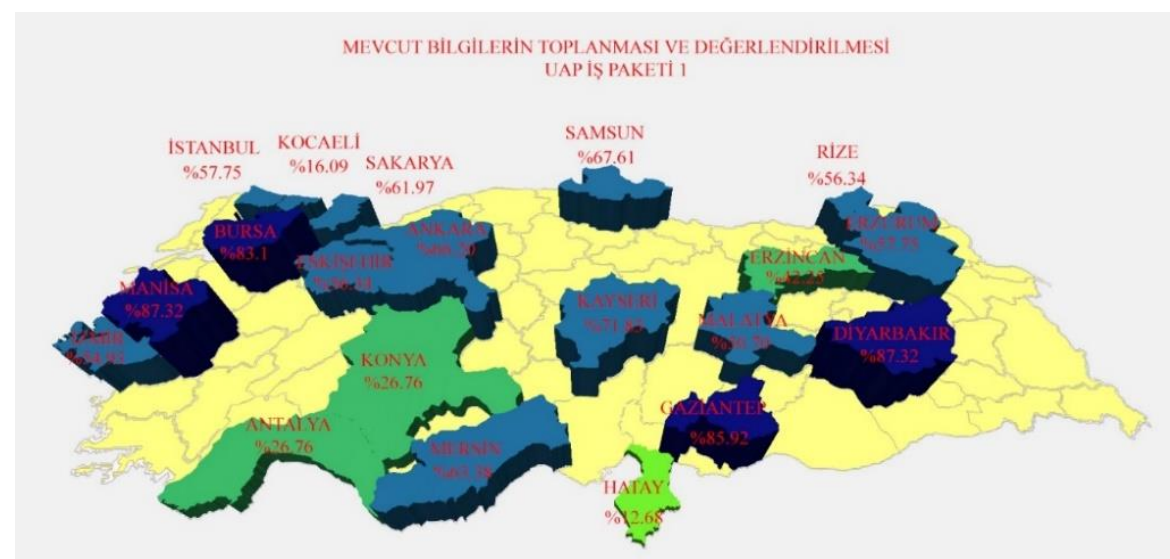

Harita 2. Mevcut Bilgilerin Toplanması ve Değerlendirilmesi

Tablo'dan ve görselden görüldüğü üzere İş Paketi 1 Mevcut bilgilerin toplanması kapsamında en fazla iş kaleminin Diyarbakır ve Manisa ilini ele alan ulaşım ana planında tamamlandığı görülürken oranının altında yaklaşık 9 kentin ortalama değer olan $\% 56,69^{\prime}$ un altında kaldığı görülmektedir. Toplamda ise incelenen 20 kentten yüzde 55 'inin ortalama üzerinde bir iş tamamlama değerine sahip olduğu görülmektedir.

Ulaşım ana planları açısından iş akışında mevcut bilgilerin toplanmasını yeni bilgilerin toplanması izlemektedir. Bu açıdan 20 kentin ulaşım ana pla$\mathrm{n}$ bazında iş kalemlerinde tamamladığ 1 işler tabloda olduğu gibidir.

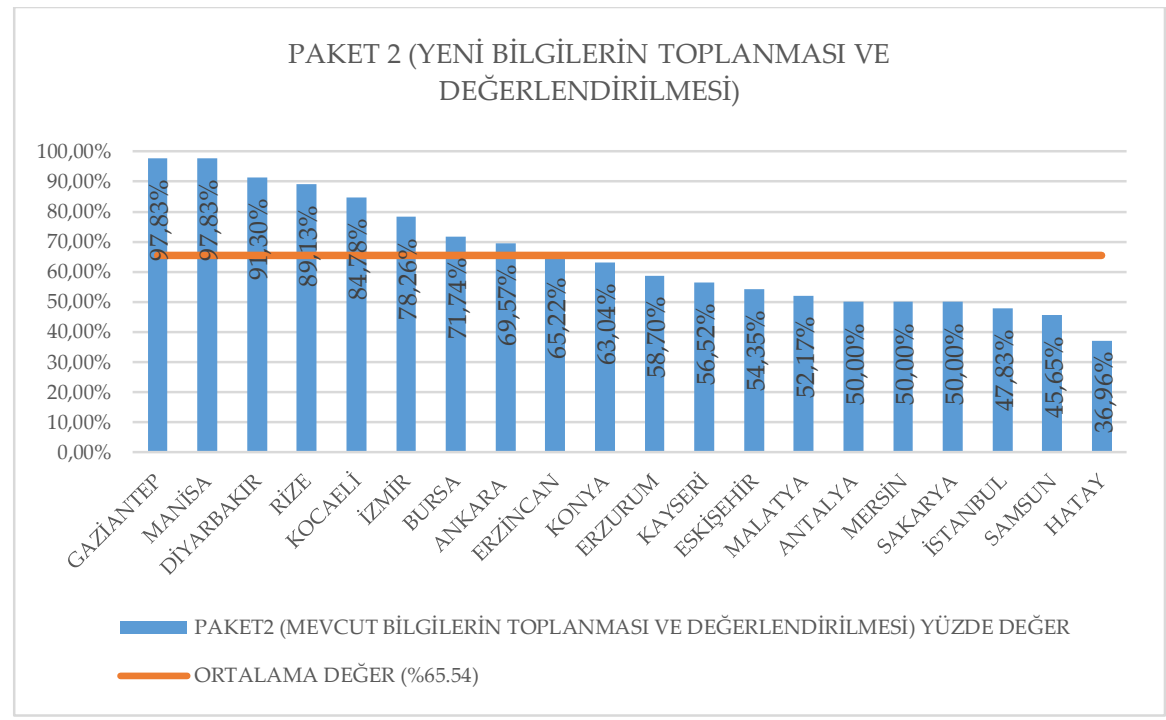

Grafik 2. İş Paketi 2 Kapsamında Yapılan Değerlendirme 
Paket 2 kapsamındaki grafik incelendiğinde ortalama \%65,54'lük bir başarı sağlandığı görülmektedir. Toplamda 12 ilin ortalama başarı sınırının altında kaldığı görülmektedir. Paket 2'nin daha az başarı sağlanan iş paketlerinden biri olduğu görülmektedir.

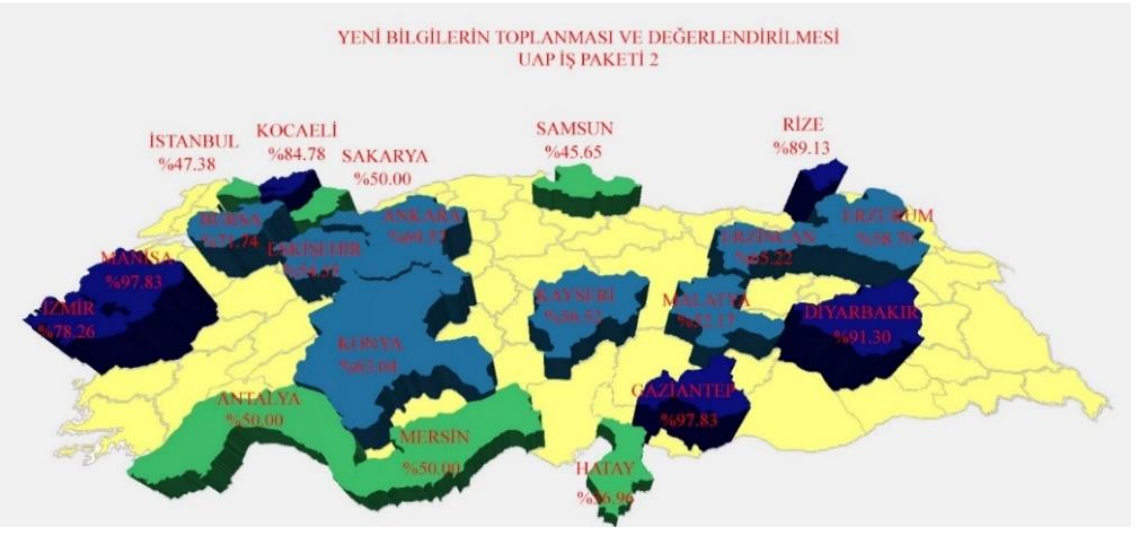

Harita 3. Yeni Bilgilerin Toplanması ve Değerlendirilmesi

Tablodan görüldüğü üzere iş paketi 2 kapsamında yapılan değerlendirmede yaklaşık 11 adet kentin ortalama değer olan \%65'in altında kaldığı görülmektedir. En yüksek iki değeri elde eden neredeyse tam puanı elde edebilecek bir değere ulaştığ1 görülmektedir. İş paketi iki konusunda ise toplamda sadece 20 kentin \% 45'lik' bir diliminin ortalamanın üzerine çıktığı görülmektedir. Genel olarak ulaşım ana planlarının bilgi toplamaya ilişkin kısımları incelendiğinde yeni bilgi toplama açısından daha başarılı sonuçların alındığı görülmektedir.

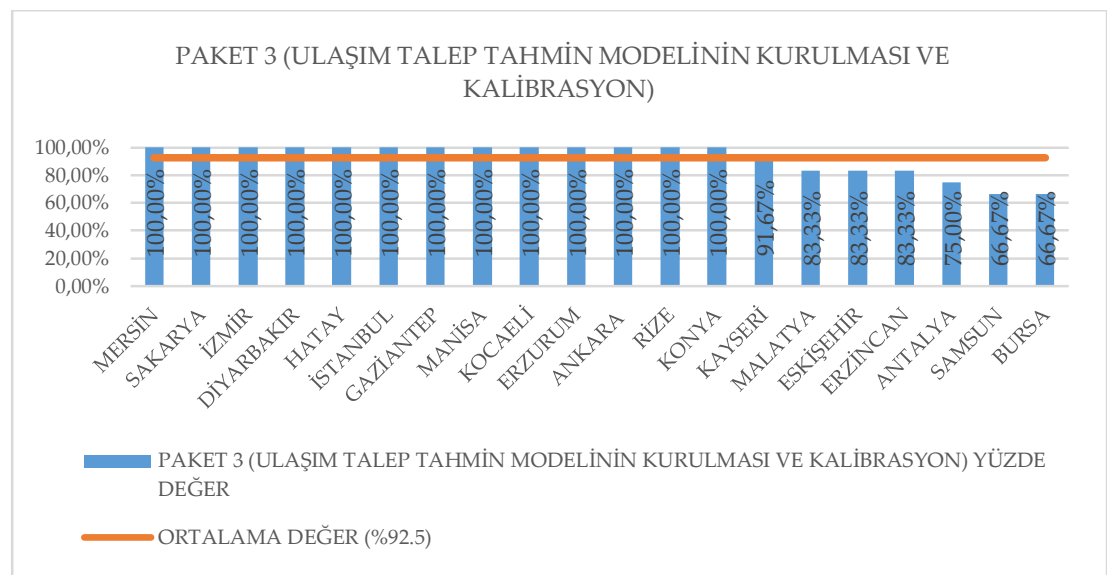

Grafik 3. İş Paketi 3 Kapsamında Yapılan Değerlendirme 
Paket 3 kapsamındaki grafik incelendiğinde ortalama \%92,5'lik bir başarı sağlandığı görülmektedir. Toplamda 7 ilin ortalama başarı sınırının altında kaldığ görülmektedir. Paket 3 konusunda ortalama başarının yüksek seviyede olması en dikkat çeken unsurdur.

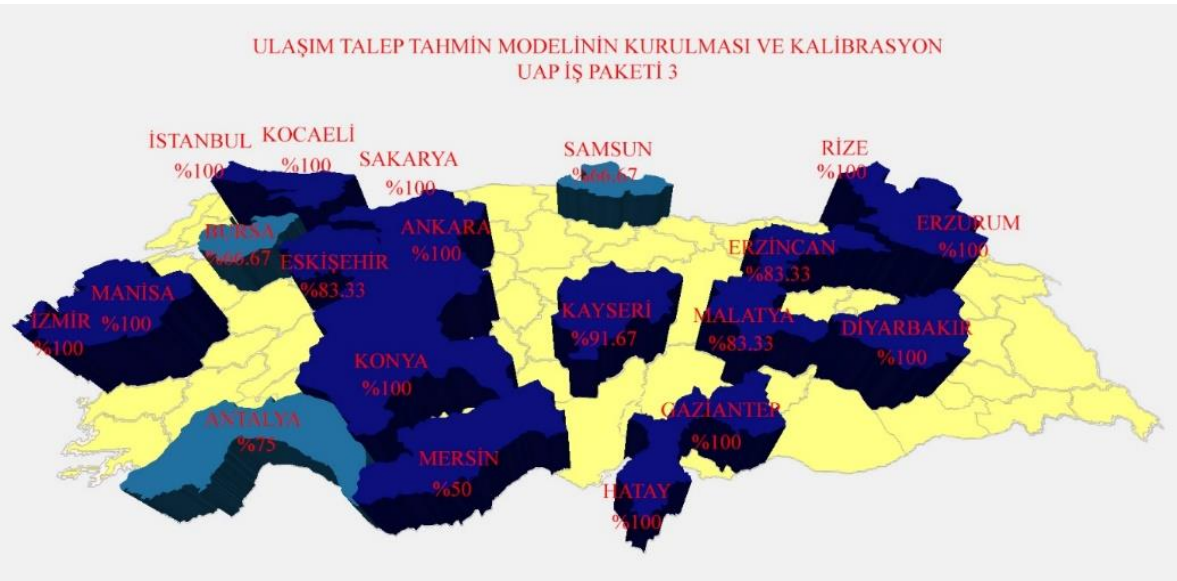

Harita 4. Ulaşım Talep Tahmin Modelinin Kurulması ve Kalibrasyon

Ulaşım talep tahmin modelinin kurulması ve kalibrasyon çalışmalarının ulaşım ana planları içindeki konumu gelecekteki süreci matematiksel hesaplar ile ortaya koyarak açıklamalar yapmak olarak ifade edilebilir. Tabloda görüldüğü üzere iş paketi 3 kapsamında yapılan değerlendirme ulaşım ana planlarının önemli bir çoğunluğu ulaşım talep tahmin modelinin kurulması ve kalibrasyon çalışmaları açısında bütün gereklilikleri başarı ile karşılamaktadır.

Toplamda 12 puanlık bir iş kaleminden oluşan ulaşım tahmin modelinin kurulması ve kalibrasyon çalışmalarında ulaşım ana planları açısından en az 8 puan alınmış olması genel olarak ulaşım ana planlarında talep tahmin modelinin kurulması ve kalibrasyon çalışmalarının tamamlanmasının daha fazla dikkat edilen bir konu olarak görüldüğüne işaret etmektedir.

Ulaşım ana planı çalışmaları bir planlama faaliyeti olduğundan dolayı geleceğe yönelik kestirimlerin olması gerekmektedir. Yapılan kestirimler ile birlikte ulaşım ana planlarının öneriye yönelik olan bölümlerinde daha detaylı sonuçlar geliştirilebilmektedir.

Hedef yılı projeksiyonuna ilişkin unsurlar;

- Nüfus,

- Arazi Kullanım, 
- İş gücü,

- Eğitim,

- Kamusal Donat1

Kavramlarına yönelik gerçekleştirilmektedir.

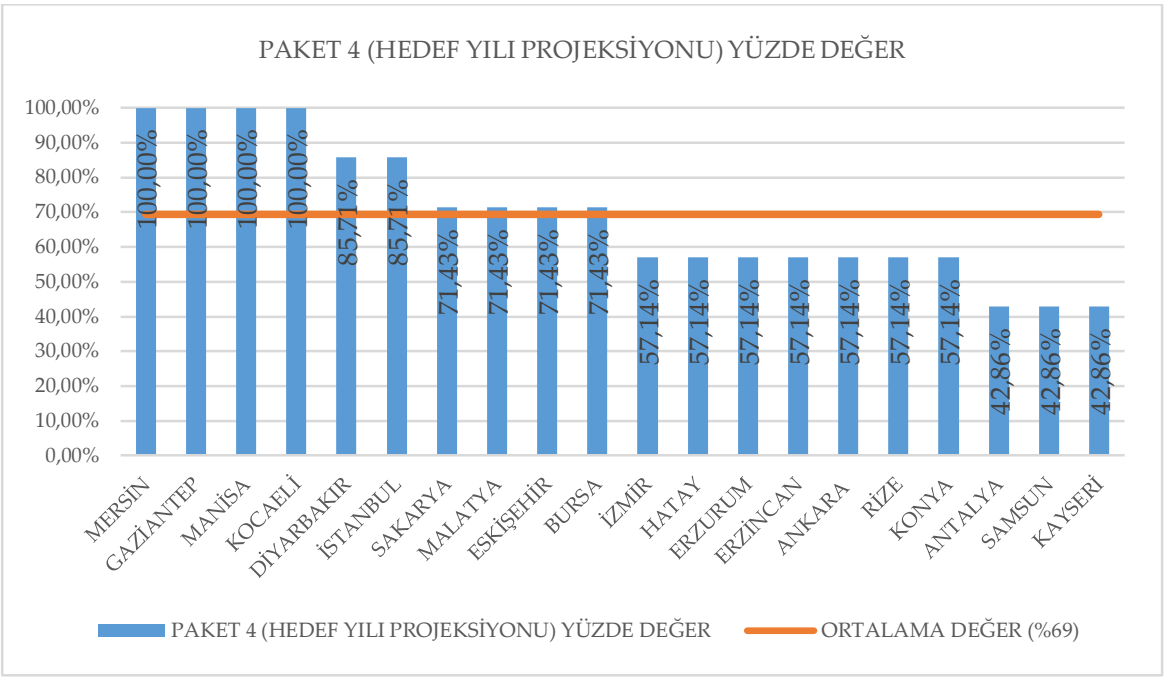

Grafik 4. İş Paketi 4 Kapsamında Yapılan Değerlendirme

Paket 4 kapsamindaki grafik incelendiğinde ortalama \%69'luk bir başarı sağlandığı görülmektedir. Toplamda 10 ilin ortalama başarı sınırının altında kaldığı görülmektedir. Bir diğer ifade ile Paket 4 konusunda ortalama başarı iller bazında yarı yarıya sağlanmaktadır.

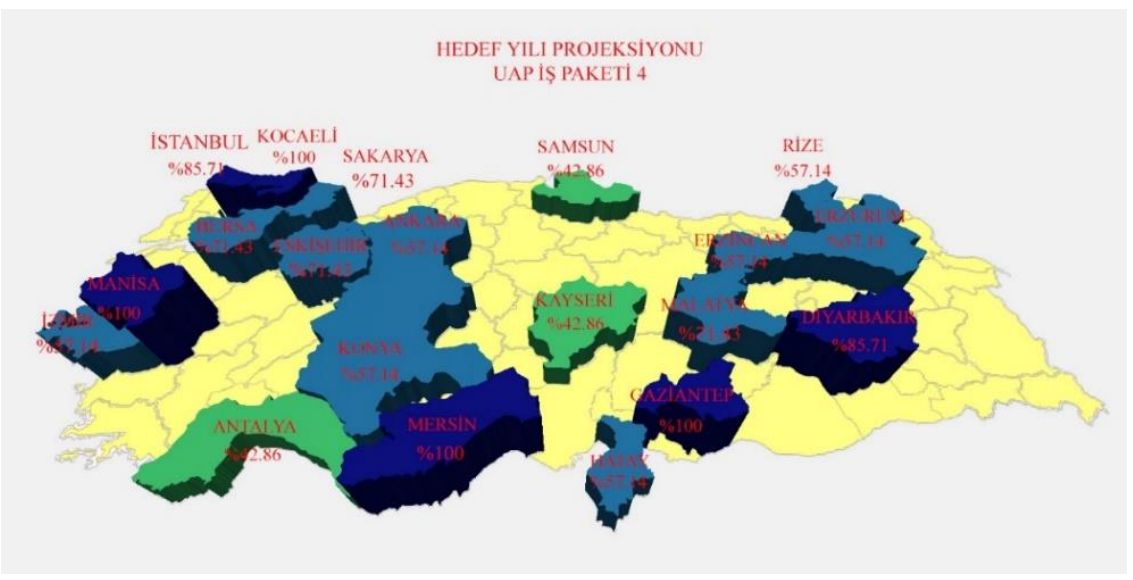

Harita 5. Hedef Yllı Projeksiyonu 
İş paketi 4, hedef yılı projeksiyonlarının yapılması konusunda 20 kentin ulaşım ana planının incelenmesi sonucunda 20 kentin 10 tanesinin $(69,29)$ ortalama değerin altında bir iş tamamlaması sağladığı görülmektedir.

İş paketi 5 bir diğer ifade ile yetersizlik ve sorun analizi ulaşım ana planının ortaya konulma amacını öz olarak ifade eden bir iş kalemidir.

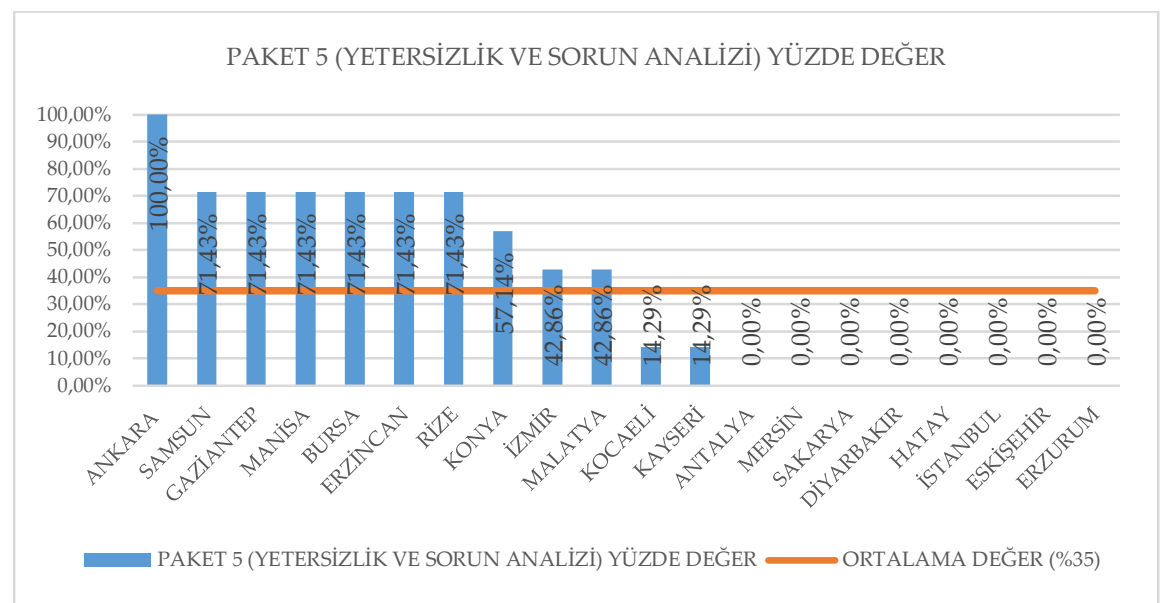

Grafik 5. İş Paketi 5 Kapsamında Yapılan Değerlendirme

Paket 5 kapsamındaki grafik incelendiğinde ortalama \%35'lik bir başarı sağlandığı görülmektedir. Toplamda 10 ilin ortalama başarı sınırının altında kaldığı görülmektedir. Bu iş paketi kapsamında ortalamanın düşük çıkması birçok ilin paket 5 kapsamında iş ortaya koymaması veya yetersiz koymasından kaynaklıdır. Buradan çıkarılacak bir diğer sonuç ise ulaşım ana planı hazırlayan birçok ekibin paket 5 kapsamındaki işlere odaklanmaması yönündedir.

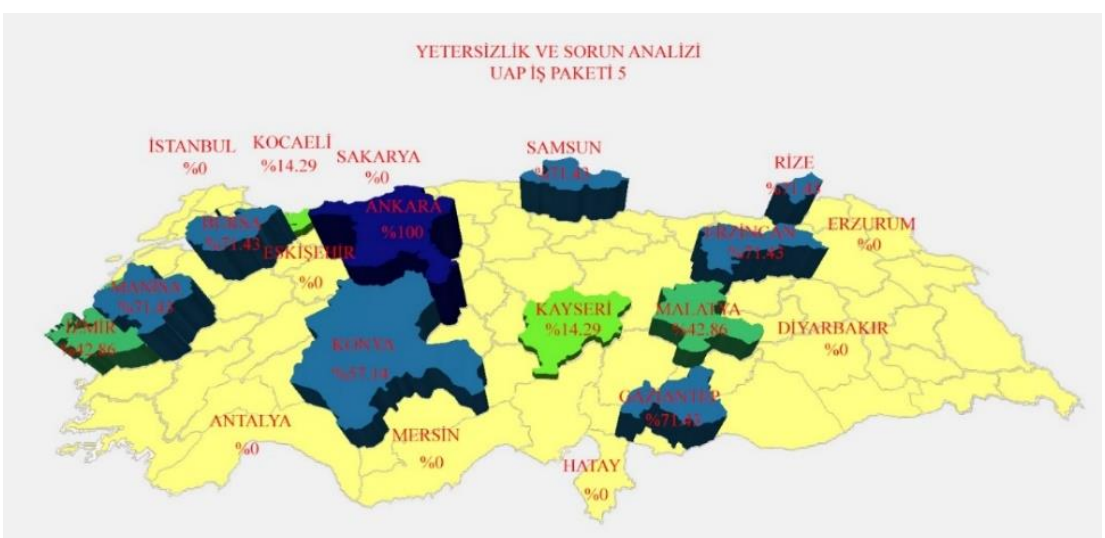

Harita 6. Yetersizlik ve Sorun Analizi 
Tabloda görüldüğü kadarıyla yetersizlik ve sorun analizi adı altında sadece tek bir kentin \%100'lük bir iş tamamlama süreci oluşturduğu görülmektedir. Toplamda 20 kentin \%40'lik bir kismının yetersizlik ve sorun analizinde herhangi bir puan alamadığı görülmektedir.

Ulaşım ana planı çalışmaları kentte karşılaşılan ve gelecekte gerçekleşmesi muhtemel sorun ve yetersizliklere yönelik çözüm gerçekleştirme amac1 taşınarak yapıldığından sorun ve yetersizliklerin tespitine yönelik olarak herhangi bir tespit yapılmadığı gözlemlenen ulaşım ana planlarının kent içi ulaşım problemlerine çözüm üretme de ne kadar etkili olacağı tartışma konusu olarak ele alınabilir.

Ulaşım ana planı çalışmaları kapsamında üretilen iş kalemlerinden birisi de alternatiflerin geliştirilmesi ve modelde test edilmesi şeklindedir.

Alternatif geliştirme ve ulaşım modelinde test edilmesi konusunda ulaşım ana planlarının en fazla \%100'lük en az ise \%33'33'lük bir başarım sağladığı görülmektedir.

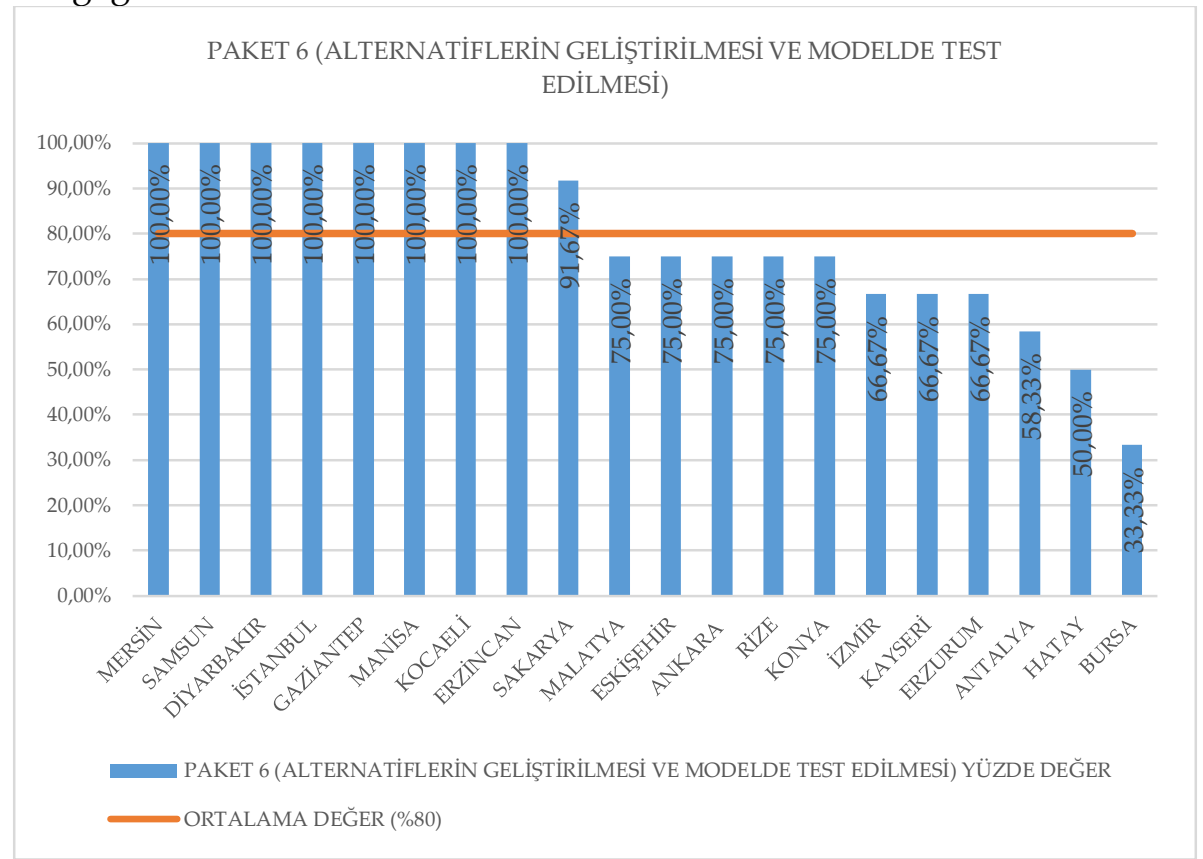

Grafik 6. İş Paketi 6 Kapsamında Yapılan Değerlendirme

Paket 6 kapsamındaki grafik incelendiğinde ortalama \%80'lik bir başarı sağlandığı görülmektedir. Toplamda 11 ilin ortalama başarı sınırının altında kaldığı görülmektedir. Paket 6 genel olarak başarı ortalaması yüksek olan bir iş paketi olarak karşımıza çıkmaktadır. 


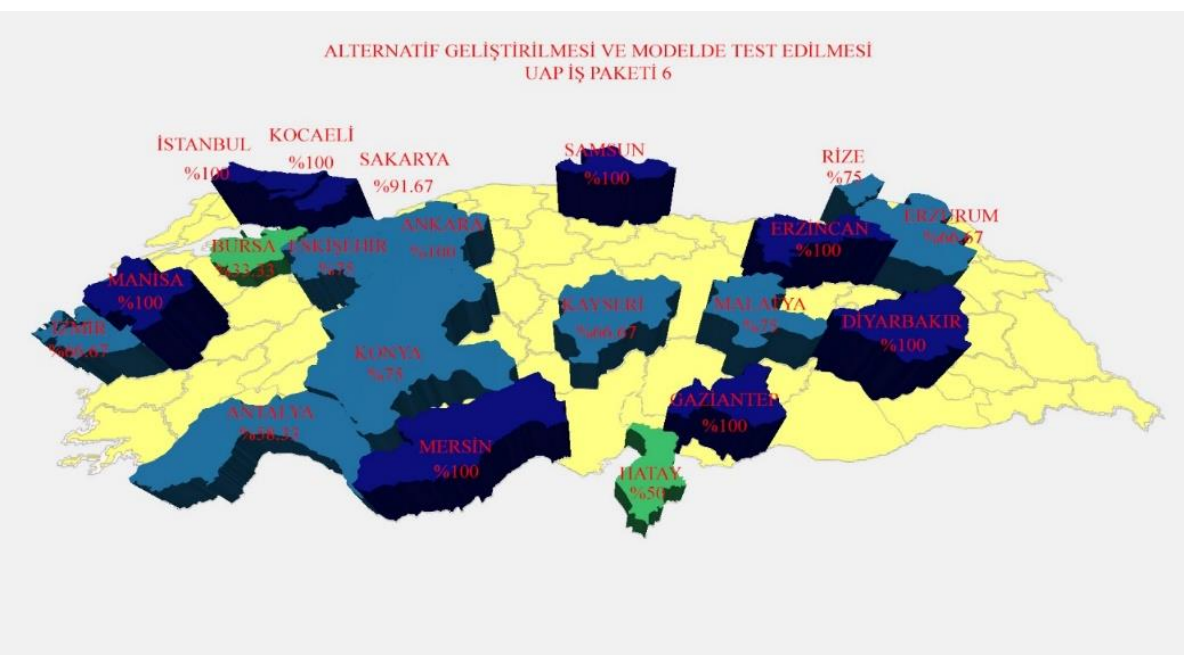

Harita 7. Alternatif Geliştirilmesi ve Modelde Test Edilmesi

İş paketi 6 yani alternatiflerin geliştirilmesi ve modelde test edilmesi sürecinde senaryo kavramına ilişkin olarak;

- Senaryo Hazırlama

- Senaryo Ön Değerlendirmesi

- Senaryoların Karşılaştırılması

- Senaryoların Çok Ölçütlü Değerlendirilmesi

- Senaryoların Değerlendirilmesi

Gibi konulara ilişkin iş kalemlerinin yapılıp yapılmadığına bakılmaktadır.

Ulaşım ana planları açısından bakıldığında önemli bir çoğunluktaki ulaşım ana planlarının maksimum puan seviyesinde iş tamamladıkları görülmektedir. Buradan çıkan yoruma göre ulaşım ana planlarında senaryo geliştirme konusuna hassasiyetle yaklaşıldığ 1 ifade edilebilir.

Ulaşım ana planının son aşamasını uygun bir değerlendirme yöntemi ile seçilen alternatif senaryonun üzerinden ulaşım ana planı çalışmasının sonuçlandırması oluşturmaktadır. Her ne kadar sonuç kavramına yönelik bir iş kalemi ifade edilse de bu iş kalemi çok sayıda alt iş kalemine ayrılmaktadır. Bundan dolayı seçilen alternatifin ulaşım ana planı olarak hazırlanması ayrıca hassasiyet gösterilmesi bir iş paketi olarak değerlendirilebilir. 


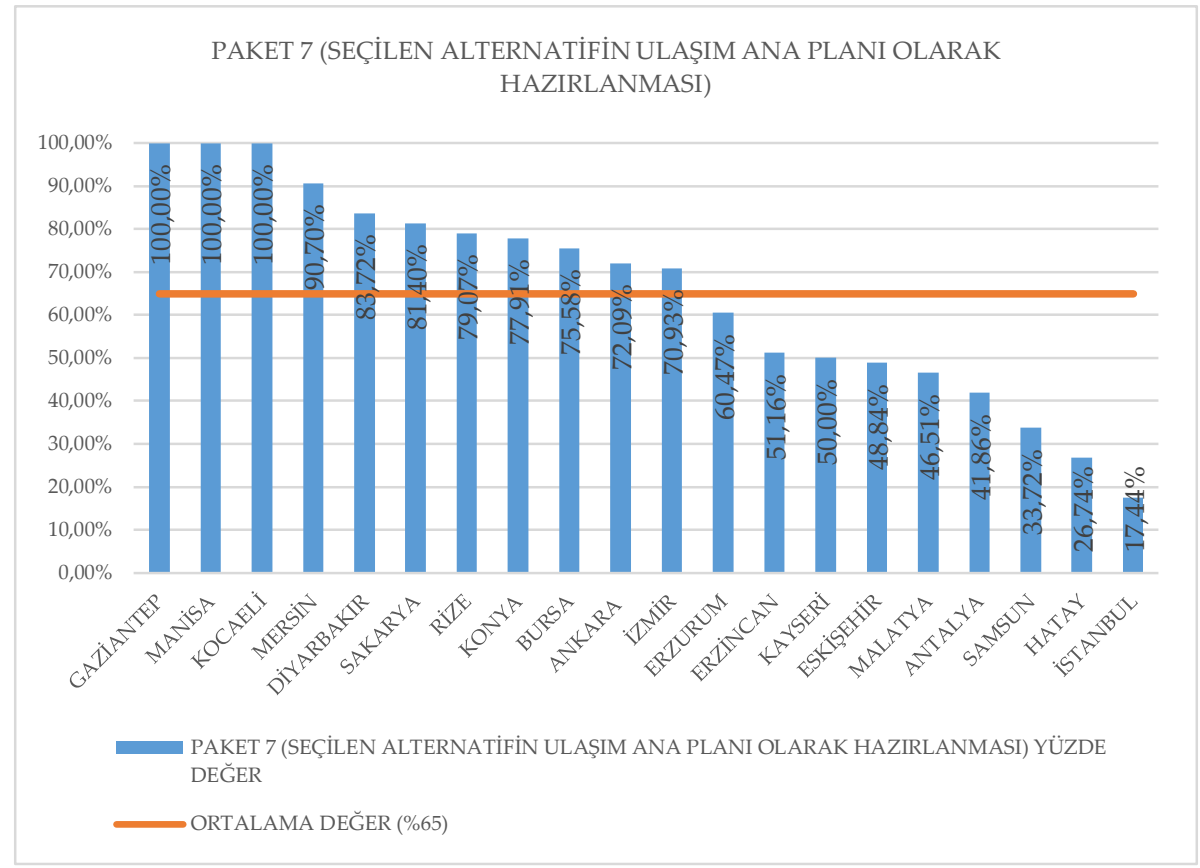

Grafik 7. İş Paketi 7 Kapsamında Yapılan Değerlendirme

Paket 7 kapsamındaki grafik incelendiğinde ortalama \%65'lik bir başarı sağlandığı görülmektedir. Toplamda 9 ilin ortalama başarı sınırının altında kaldığı görülmektedir.

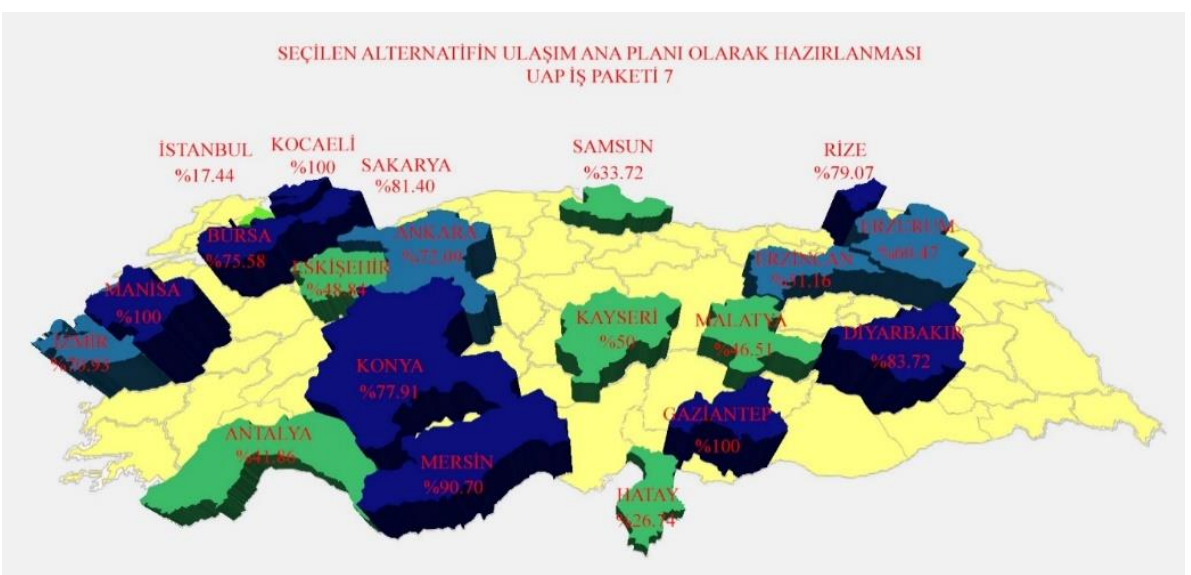

Harita 8. Seçilen Alternatifin Ulaşım Ana Planı Olarak Hazırlanması 
20 kentin ulaşım ana planı incelendiğinde yaklaşık yüzde 70'lik bir dilimin alınabilecek 86 puanın yarısını sağlayacak bir şekilde iş tamamladığ görülmektedir.

Çalışma kapsamında toplamda 20 kentin ulaşım ana planı incelemektedir. İncelenen çalışmalar farklı iş paketleri kapsamında değerlendirilmekte olup her bir iş paketi için ulaşım ana planlarının farklı seviyelerde iş kalemini tamamladığı görülmektedir. Her bir paket açısından kıyaslandığında da ulaşım ana planlarında farklı seviyelerde iş tamamlanmış olması ve ilgili pakette ortalama değerden daha fazla iş kaleminin tamamlanmasındaki farklılık paketlerin zorluk derecesi ile ilgili fikir verebilmektedir.

Tablo 5. Ortalama Değer Tablosu

\begin{tabular}{cc}
\hline Paket Tanımı & $\begin{array}{c}\text { Ortalama Değerden Daha } \\
\text { Fazla İs Kalemi Tamamla- } \\
\text { yan Kentlerin Sayısı }\end{array}$ \\
\hline Mevcut Bilgilerin Toplanması ve Değerlendirilmesi (P1) & 11 \\
\hline Yeni Bilgilerin Toplanması ve Değerlendirilmesi (P2) & 8 \\
\hline Ulaşım Talep Tahmin Modelinin Kurulması ve Kalibrasyonu (P3) & 13 \\
\hline Hedef Yılı Projeksiyonu (P4) & 10 \\
\hline Yetersizlik ve Sorun Analizi (P5) & 10 \\
\hline Alternatiflerin Geliştirilmesi ve Modelde Test Edilmesi (P6) & 9 \\
\hline Seçilen Alternatifin Ulaşım Ana Planı Olarak Hazırlanması (P7) & 11 \\
\hline
\end{tabular}

Tabloda görüldüğü üzere her bir pakette ortalama iş tamamlama değerinden daha fazla iş kalemi tamamlayan ulaşım ana planı bir diğer ifade ile kentlerin sayısı yer almaktadır. Buradan hareketle yeni bilgilerin toplanması ve değerlendirilmesi konusu zor bir iş paketi olarak değerlendirilebilecekken ulaşım talep tahmin modelinin kurulması ve kalibrasyonu çalışmalarını kapsayan iş paketinin ise daha fazla ulaşım ana planında tamamlanmaya çalışılan bir iş paketi olduğu görülmektedir. 


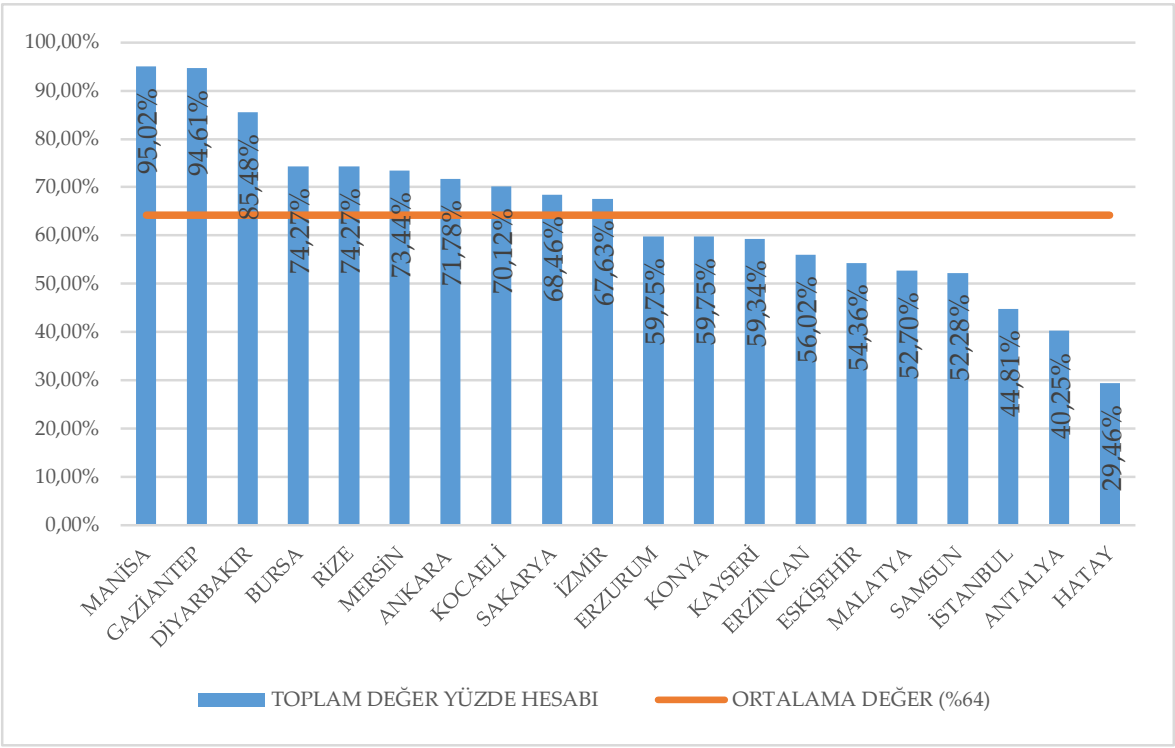

Grafik 8. Toplam Değerlendirme

Toplam başarıya grafik incelendiğinde ortalama \%64'lik bir başarı sağlandığı görülmektedir. Toplamda 10 ilin ortalama başarı sınırının altında kaldığı görülmektedir.

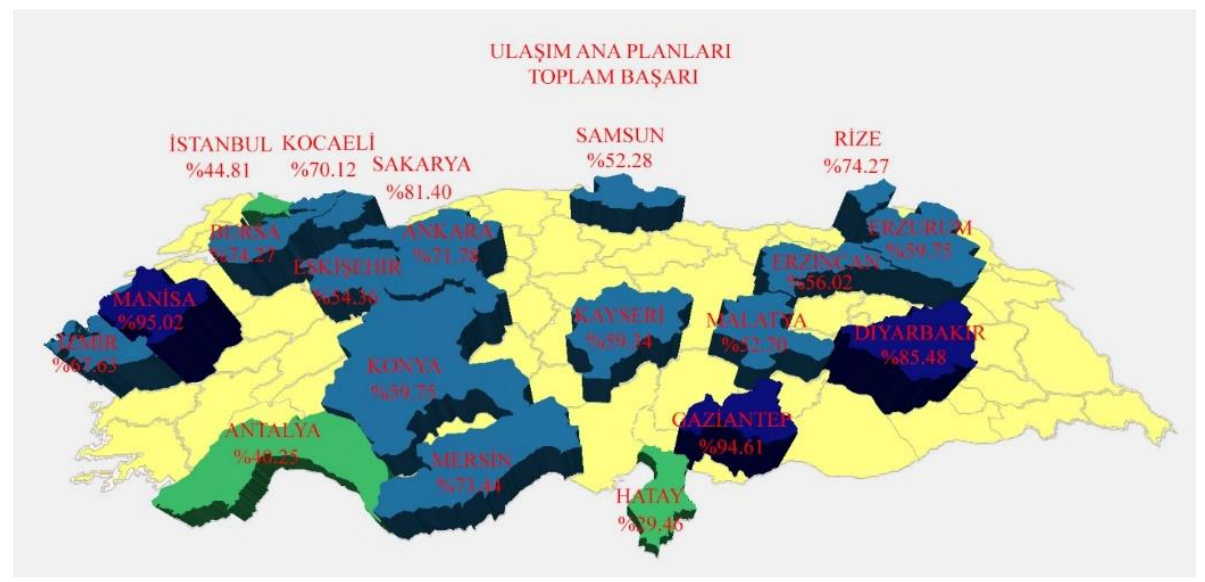

Harita 9. Ulaşım Ana Planları Toplam Başarı

\section{Tartışma ve Sonuç}

Bu çalışma, 20 kentte yapılmış ulaşım ana planı çalışması üzerinden Türkiye'de ulaşım ana planı işlerinin tamamlanmasında yaşanan, Türki- 
ye Belediyeler Birliğinin hazırlamış olduğu ulaşım planlama çalışmaları ve ulaşım ana planı hazırlama kılavuzundan yararlanarak iş sürecini daha iyi anlamak amaciyla oluşturulmuştur.

Yapılan incelemeler doğrultusunda kentlerin farklı dinamiklere ve farklı sorunlara sahip olması durumunun kent için bir ulaşım ana planı söz konusu olduğunda farklı nitelikte çalışmaları gerektirebileceği görülmektedir. Çalışmanın sonuçlarına göre Türkiye'de ulaşım ana planlarını hazırlayan ekiplerin ulaşım ana planında hassasiyet gösterdiği konular şu şekilde sıralanmaktadır.

1. Ulaşım Talep Tahmin Modelinin Kurulması ve Kalibrasyonu (P3)

2. Seçilen Alternatifin Ulaşım Ana Planı Olarak Hazırlanması (P7) Mevcut Bilgilerin Toplanması ve Değerlendirilmesi (P1)

3. Hedef Yılı Projeksiyonu (P4) - Yetersizlik ve Sorun Analizi (P5)

4. Alternatiflerin Geliştirilmesi ve Modelde Test Edilmesi (P6)

5. Yeni Bilgilerin Toplanması ve Değerlendirilmesi (P2)

Buradan görüldüğü üzere ulaşım talep tahmin modelinin kurulması ve kalibrasyonu konusunda ekiplerin daha hassas bir yaklaşım gösterdiği anlaşılmakta iken yeni bilgilerin toplanması konusunda aynı hassasiyet duygusunun sağlanmadığı görülmektedir.

İş paketi 5 yani sorun ve yetersizlik tespiti ulaşım ana planı yapılmasının en önemli gerekliliklerindendir. Ulaşım ana planları kentteki ulaşım sorunlarını çözmeye yönelik yapıldığından dolayı sorun ve yetersizlikler açısından incelenen birçok örnekte sorun ve yetersizlik tespitine ilişkin iş kalemlerinin üretilmemiş olması dikkat çekmektedir.

Ulaşım ana planları kapsamında sadece Türkiye Belediyeler Birliğinin hazırlamış olduğu ulaşım planlama çalışmaları ve ulaşım ana planı hazırlama kılavuzundan yararlanarak değerlendirilmekte ancak farklı dinamiklere sahip kentlerde farklı iş kalemlerinin gerçekleştirilerek ulaşım ana planlarının tamamlanması durumu dikkat çekmektedir.

$\mathrm{Bu}$ çalışma da görüldüğü kadarıyla farklı seviyelerde tamamlanan iş paketlerinin olması, ulaşım ana planlarını oluşturan 7 ana iş kaleminin tamamlanmasının farklı türde işler gerektirmesinden kaynaklanmaktadır. Farklı türde çalışmalara gereksinim duyulan iş paketlerinin bahsedilen durumundan dolayı ulaşım ana planının her iş paketinin aynı hassasiyette hazırlanıp hazırlanmaması gerekliliğine ilişkin kesin bir yargıya varmak bir başka çalışmanın konusu olabilir. 
İş paketlerine ilişkin önem derecelerinin belirlendiği bir başka çalışmanın sonuçlarına göre ise ulaşım ana planı çalışmalarının iş akış süreci yeniden düzenlenerek verimli bir şekilde üretilen bütün ulaşım ana planlarının aynı başarı seviyesine gelmesine katkıda bulunulabilir. 


\title{
Extended Abstract
}

\section{Analysis of the Project Production Process from Theory to Practice of Strategic Plans: Sample of Great Municipality Transportation Master Plans \\ *}

\author{
Hayri Ulvi \\ Gazi University
}

Transportation master plans are among the plans of $1 / 25,000$ and 1/5,000 scales within the plan hierarchy and are known as one of the most important planning tools commonly used to solve transportation problems in urban areas. Even though many cities are facing problems in terms of different transportation issues, transportation master plans allow solutions for potential problems from various perspectives. Transportation master plans are composed of work items that need to be completed with precision from the beginning to the end, since realization of transportation master plans necessitates consumption of large resources in order to solve problems. In order to complete the mentioned work items with precision, there are the stages of the transportation master plan workflow which are put forward by transportation experts. For the successful completion of transportation master plans, Union of Municipalities of Turkey (TBB) is one of the institutions in Turkey, which define the transportation master plan workflow process. A document, which is expected to be used by the said institution and as a tool for the preparation of transportation master plans, is included in the literature as a guide for preparing transportation master plans. In this study, a number of transportation master plans realised in different provinces of Turkey are handled in detail and the completion level of work in different provinces are examined on the basis of the guide of Union of Municipalities of Turkey. Transportation master plans aim to solve the urban transportation problems by focusing mainly on urban areas in a city. A transportation master plan should be considered as a concept to; alleviate transport-related problems of city, obtain new information in written and drawn forms, conduct estimation studies in accordance with the information obtained, form numerical modelling of the city's near future transport via estimations and 
to reduce effects of deficiencies, problems and congestions taking numerical modelling into account. Although transportation master plans seem to require a similar workflow in cities in terms of the problems it aims to solve, differences are observed in terms of business process due to the dynamic nature of each city. Within the scope of transportation master plans in Turkey, one of the institutions that provide financing to the projects is municipalities, which are among local administrations. Municipalities use transportation master plans as means to solution for the transportation problems of their responsibility area. The document prepared by Union of Municipalities of Turkey guides to increase the usage of transportation master plans to develop solutions, while detailing workflows for formation of them. It can be put that the said document, which is the guide of preparing transportation master plans, divides transportation master plans into 7 main work items in order to easily understand the required activities. 7 main items can be expressed as follows:

- Collection of available information

- Collection of new information

- Establishment of demand forecasting model

- Target year forecast

- Problem detection

- Creating alternative solutions and testing them in the model

The collection of existing information is followed by the acquisition of new information needed, the establishment of a transport demand forecasting model and the calibration of it.

Since the planning activity includes the decisions regarding the predictions for the future, it is necessary to make forecasts for the target year, this element is an important part of the transportation master plan. Transportation master plans are developing mainly to solve the transportation problems in the related settlement area. This situation requires a detailed inadequacy and problem analysis within the framework of transportation master plans. In terms of transportation master plans, it is seen that majority of transportation master plans complete work at maximum levels. Taking transportation master plans of twenty different provinces in Turkey and guide of Union of Municipalities into account, this study is conducted in order to comprehend business workflows lead to completion transportation master plans Turkey. In the light of the examinations, it is seen that different dynamics and different problems of cities may require different procedures when a transportation master plan is to be established. According to the 
results of the study, subjects about which teams preparing the master plans for transport in Turkey showed sensitivity are listed respectively as follows: 1. Establishment and calibration of transportation demand forecasting model (P3)

2. Preparing selected alternative as transportation master plan (P7) - Collection and evaluation of existing information (P1)

3. Target year projection (P4) - Inadequacy and problem detection (P5)

4. Formulation of alternatives and testing in model (P6)

5. Collection and evaluation of new information (P2)

According to the ranking above, it is understood that the teams have taken a more sensitive approach in establishing and calibrating the transportation demand forecasting model while same amount of sensitivity does not exist for the collection of new information.

Work package 5, that is, the identification of problems and inadequacies, is one of the most important requirements of the transportation master plan. Since the main transportation plans are designed to solve the transportation problems in the city, it is noteworthy that business items related to the detection of problems and inadequacies were not produced. Within the scope of the transportation master plans, only the transportation master plan guide prepared by the Union of Municipalities of Turkey is taken into consideration; however, in cities with varying dynamics the completion of the transportation master plans draws remarkably different tracks.

As can be seen in this study, the existence of work packages completed at different levels stems from the fact that the completion of the 7 main work items constituting the main plans of transportation requires different types of work. According to the results of another study in which the importance levels of work packages are examined, rearrangement of workflows of transportation master plan may contribute to efficiency transportation master plans. 


\section{Kaynakça/References}

Önder, H.G, Akdemir, F. (2019). Türkiye' deki kentiçi raylı toplu taşıma sistemlerinin ulaşım ana planları bağlamında değerlendirilmesi. Demiryolu Mühendisliği Dergisi, 10, 23-37.

Akbulut, F. (2016). Kentsel ulaşım hizmetlerinin planlanması ve yönetiminde sürdürülebilir politika önerileri. Kastamonu Üniversitesi İktisadi ve İdari Bilimler Fakültesi Dergisi, 11(1), 336-355.

Ayataç, H. (2016). Kentsel ulaşım planlaması ve İstanbul. İTÜ Vakfi Dergisi, 71, 3135.

Hamurcu, M., ve Eren, T. (2018). Kent içi ulaşım için bulanık ahp tabanlı vikor yöntemi ile proje seçimi. Engineering Sciences, 13(3), 217-228.

Hamamcıoğlu, C. (2009). Ulaşım ă̆ının kentsel hizmet alanlarının yerseçimine etkilerinin istanbul tarihi yarımada örneğinde değerlendirilmesi. Doktora tezi.YÖK tez merkezi. (243869).

Akman, G., ve Alkan, A. (2016). İzmit kent içi ulaşımda alternatif toplu taşıma sistemlerinin aksiyomlarla tasarım yöntemi ile değerlendirilmesi. Pamukkale University Journal of Engineering Sciences, 22(1), 54-63.

Oral, M. Y. (2011). Şehirlerde yetki alanı ve arazi kullanışlarındaki değişimlerin ulaşım planlama süreci üzerindeki olası etkileri-izmir örneği. Dokuz Eylül Üniversitesi Denizcilik Fakültesi Dergisi, 3 (1), 73-85.

Özalp, M., ve Öcalır, E. V. (2008). Türkiye'deki kentiçi ulaşım planlaması çalışmalarının değerlendirilmesi. METU Journal of the Faculty of Architecture, 25(2), 7197.

Türkiye Belediyeler Birliği. (2014). Ulaşım planlama çalışmaları ve ulaşım ana planı hazırlama kılavuzu. Ankara, TBB Yayınları.

Manisa Büyükşehir Belediyesi-Mescioğlu Mühendislik Müşavirlik A.Ş. (2014). Manisa ulaşım ana planı (2014-2034). Manisa, Manisa Büyükşehir Belediyesi

Gaziantep Büyükşehir Belediyesi-Boğaziçi Proje Mühendislik Planlama İnş. San, ve Tic. Ltd. Şti. (2015). Gaziantep ulaşım ana planı (2015-2030). Gaziantep, Gaziantep Büyükşehir Belediyesi

Diyarbakır Büyükşehir Belediyesi-Boğaziçi Proje Mühendislik Planlama İnş. San, ve Tic. Ltd. Şti. (2011). Diyarbakır ulaşım ana planı (2011-2014). Diyarbakır, Diyarbakır Büyükşehir Belediyesi

Bursa Büyükşehir Belediyesi. (2010). Bursa ulaşım ana planı (2010-2030). Bursa, Bursa Büyükşehir Belediyesi.

Mersin Büyükşehir Belediyesi-Boğaziçi Proje Mühendislik Planlama İnş. San, ve Tic. Ltd. Şti. (2010). Mersin ulaşım ana planı (2010-2025). Mersin, Mersin Büyükşehir Belediyesi.

Gazi Üniversitesi AUAP Ofisi - Ankara Büyükşehir Belediyesi. (2013). Ankara UAP - Ankara metropoliten alanı ve yakın çeoresi ulaşım ana planı (2013). Ankara, Gazi Üniversitesi AUAP Ofisi - Ankara Büyükşehir Belediyesi. 
Kocaeli Büyükşehir Belediyesi. (2010). Kocaeli ulaşım ana planı açıklama raporu. Kocaeli, Kocaeli Büyükşehir Belediyesi.

Sakarya Büyükşehir Belediyesi - Mescioğlu Mühendislik Müşavirlik A.Ş. Sakarya UAP. (2011). Sakarya ulaşım ana planı (2011-2023). Sakarya, Sakarya Büyükşehir Belediyesi.

İzmir Büyükşehir Belediyesi. (2009). İzmir ulaşım ana planı. İzmir, İzmir Büyükşehir Belediyesi.

Erzurum Büyükşehir Belediyesi- Boğaziçi Proje Mühendislik Planlama İnş. San, ve Tic. Ltd. Şti. (2013). Erzurum ulaşım ana planı. Erzurum, Erzurum Büyükşehir Belediyesi.

Konya Büyükşehir Belediyesi - Yüksel Proje ve Ulaşım Art. (2016). Konya büyü̈şsehir alamı kentiçi ve yakın çevre ulaşım master planı (2001). Konya, Konya Büyükşehir Belediyesi.

Kayseri Büyükşehir Belediyesi. (2016). Kayseri ulaşım ana planı (2016-2040). Kayseri, Kayseri Büyükşehir Belediyesi.

Gazi Üniversitesi KUTEM - Erzincan Belediyesi. (2017). Erzincan ulaşım ana planı (2017). Erzincan, Erzincan Belediyesi.

Eskişehir Büyükşehir Belediyesi-İstanbul Teknik Üniversitesi, Osmangazi Üniversitesi. (2016). Eskişehir ulaştırma ana planı revizyonu sonuç raporu. Eskişehir, Eskişehir Büyükşehir Belediyesi.

Malatya Büyükşehir Belediyesi- Altyapı Mühendislik Bilişim Dan. Taah ve Tic Ltd. Şti. (2017). Malatya ulaşım ana planı (2017-2035). Malatya, Malatya Büyükşehir Belediyesi.

Samsun Büyükşehir Belediyesi. (2001). Samsun kentiçi ulaşım ana planı ve toplu taşım fizibilite etüdü. Samsun, Samsun Büyükşehir Belediyesi.

İstanbul Büyükşehir Belediyesi Ulaşım Daire Başkanlığı Ulaşım Planlama Müdürlüğü. (2011). İstanbul UAP - İstanbul metropoliten alan kentsel ulaşım ana planı. İstanbul, İstanbul Büyükşehir Belediyesi

Antalya Büyükşehir Belediyesi- Boğaziçi Proje Mühendislik Planlama İnş. San, ve Tic. Ltd. Şti. (2017). Antalya ulaşım ana planı (2017-2040). Antalya, Antalya Büyükşehir Belediyesi.

Hatay Büyükşehir Belediyesi. (2016). Hatay ulaşım ana planı. Hatay, Hatay Büyükşehir Belediyesi.

Hayri Ulvi 1998 Yılında Selçuk Üniversitesi Şehir ve Bölge Planlama Bölümünü bitirmiştir. 2002 yılında aynı üniversiteden yüksek lisansını, 2012 yılında ise Gazi Üniversitesinde doktorasını tamamlamıştır. Halen Gazi Üniversitesinde Şehir Ve Bölge Planlama bölümünde Öğretim Üyesi olup, Gazi Üniversitesi Kent İçi Ulaşım Teknolojileri Erişebilirlik Uygulama Ve Araş九ırma Merkezinin Müdürlüğünü yapmaktadir. 
Hayri Ulvi graduated from Selçuk University Urban and Regional Planning Program in 1998. He completed his master's degree at the same university in 2002, and his doctorate degree at Gazi University in 2012. At present, he works as an Assistant Professor at Gazi University Urban and Regional Planning Program, and Dr. Ulvi is the manager of Gazi University Urban Transportation Technologies Accessibility Implementation and Research Center. His research interests are Accessibility, Transportation Master Plans, pedestrian environments.

E-mail: hayriulvi@gmail.com 